UDC 005:004

DOI: https://doi.org/10.30839/2072-7941.2019.177755

\title{
CONCEPTUALIZATION OF INFORMATION-DIGITAL MANAGEMENT IN THE CONDITIONS OF TECHNOLOGICAL REVOLUTION 4.0
}

\author{
C MELNYK, VICTORIA \\ National Pedagogical Dragomanov University (Kyiv, Ukraine) \\ E-mail: doc.v.melnik@mail.ru, ORCID: 0000-0001-5976-5823
}

\section{Annotation.}

The relevance of the study of this problem is that the concept of information-digital management contributes to the development of digital society, based on a new wave of technological progress. The purpose of the study is to show how the information revolution of the XX1 century contributes to the reduction of manpower as a result of progressive robotization. There are different technologies that are used today to replace people; the need for human resources is reduced thanks to robots, computers and other high-tech gadgets. Methods of theoretical analysis - deduction and induction, historical and logical, comparative and structural-genetic analysis, informatiological method, which contribute to the penetration into the essence of the phenomenon under study as a complex phenomenon and dynamic process. Results: It has been proven that, due to the various well-known developments in information-computer technologies and robotics, many experts believe that the society is at an early stage of the new industrial (post-industrial) revolution, which in the future can change the way people live and work just like 200 years ago a steam engine did. Technological unemployment is one of the main reasons for the increase in the overall unemployment rate in Western countries over the past 30 years. Although to some extent this is connected with the demographic revolution and the changing structure of the economy in many countries, the development of information and computer technologies, as well as other types of automation and Internet have played a significant role, especially since 2000. Findings. We have shown that many jobs of cheap labor can disappear, because the digital society focuses on the development of human (intellectual) resources. The world is turning into a digital society and the world is ruled by a digit, world that is based on intelligence, mind, algorithms, digitalization. The digital society consists of a set of algorithms that are controlled by information and computer technologies that penetrate into digital management, which is based on intellectual right-minded force represented by human resources. It is human resources that develop robotics, artificial intelligence, computerization, mechanization, robotization, which are based on robotics, artificial intelligence. These varieties of digital society will accelerate the potential of the long-term productivity increase through intellectualization. Practical recommendations - to develop a small business that rests on the network of intelligent platforms and helps to create jobs on the Internet and create new types of employment.

Keywords: digital society, ideology of information and computer technologies, human resources, digital management

Relevance of the research topic. The relevance of the research topic of information-digital management in the conditions of information civilization is one of the directions of the development of society. In the conditions of the $21 \mathrm{st}$ century, the formation of modern civilization has accelerated towards globalization, as a result of which a revolution occurred 
in the means of communication, which gave rise to many social and economic problems of digital society. The development of informationdigital management is promoted by the "knowledge society", the computer revolution, the essence of which is in the cultivation of the digital economy, creative individuality, which is formed basing on information, knowledge, and intelligence. The essence of the concept of information-digital management is determined by the development of information and communication technologies that determine the rating of a country and its promotion to the level of a competitive one. The main directions of development of information and digital management are based on the foundations - economic, educational, cultural, which contribute to the improvement of the information technologies of the society and the formation of a creative and innovative personality. Digital information management is designed to deepen the importance of scientifically categorical forms of digital discourse, which contributes to the formation of the concept of digital management, which is based on the main intellectual and creative resource of society [1, p.189-193].

The problem situation is the development of the concept of information-digital management, which is not yet sufficiently developed in modern management and economic literature, therefore it is very important to study all new approaches to its development. The problem situation is the conceptualization of informationdigital management, the essence, content and main directions of development that are being introduced into the practice of the modern educational process of higher education [2, p.189-215].

Objectives of the study conceptualization of information digital management as a science, based on information and communication technologies and informatization mechanisms that help to identify the information-innovative potential of our country. The concept is based on the development of digital information standards and the implementation of intellectual human capital, which is based on information, communication, digitalization of society. Therefore, the transition to digital civilization is in the context of globalization economic, political, cultural, educational - the nature of "digital projects", which are based on the information and innovative development of society [3].

\section{Methods and research} methodology. The methodological basis for the formation of the concept of information and communication management is the informationalism studied by M. Castels (2000), as well as the autopoecisal methodology of Maturana and Varela. The methodological basis of the concepts of information-digital society is the process of re-industrialization, based on the development of industrial society in the post-industrial and information-digital. Re-

Conceptualization of information-digital management in the conditions of technological revolution 4.0 
industrialization is seen as a new stage in the development of digital society, in which science and technology are not hostile to one another, but form an eco-intelligent digital economy, based on intellectual resources and electronic digital management culture [3].

The results of the research - the formation of the concept of digital management as one of the most modern directions of development of the society in the 21 st century, digital development of all spheres of life activity, requiring the development of an information-innovative society and an information-innovative personality, is required. The concept of digital management as a science must comply with the digital way of production and management system, which is based on information and communication technologies and contribute to strengthening its information-digital culture. The task of the digital potential of society is to resist the destructive tendencies of society, which necessarily claims the formation of a creative personality that turns digitalization into creative and innovative processes. The concept of digital information management has the character of "digital projects": 1) information and communication management; 2) management of digital information resources; 3) management of digital information processing [4].

The concept of information-digital management is a set of rules, technical methods and systems that define the information and communication structure of an organization, defining the purposeful use of digitalization as the main resource on the way to the digital society of innovations. The concept of "information-digital management" includes the creation of such an information structure, where all the "parts" of digitalization provide the necessary level of coincidence of all information components on a new innovative digital basis. Digital management is seen as the foundation of an innovation society based on innovation and digitalization [5].

The concept of information-digital society is based on the principle of technological determinism, the development of science and technology, new creative technologies - nanotechnology, biotechnology, social and humanitarian technologies. As a result of the introduction of super modern technologies, innovative development of science and technology, advanced research projects, based on the digital development of technological and technical spheres of production, the introduction of intellectual resources as the main component of society, is necessary. In accordance with this, the social structures and relations of society also change, which require appropriate development, which would correspond to the technicalinnovative structure of society [6].

Digital economy, digital information management and digital culture are based on a technotronic, super-industrial, information society in which the majority of the population is concentrated in the field of digital services and consumption. Information and digital society comes to replace the industrial and labor one and is overcoming the 
industrialization in which industry is the foundation, since the information society implies the service sector and the corresponding digitization of society [7, p.39-47].

Information and digital society is no longer a "raw material warehouse" in which industrial products are accumulated and goods are overproduced and oriented towards the consumer, instead, the large databases are used in digital processing of materials and transforming it a into customer service quality through the use of information. In the conditions of information-digital society, the qualification, education, competence, intellectuality and creativity of the individual takes the place of the productivity.

The value of human activity and its focus on digitalization are determined by the number of efforts, abilities, information that are spent on it. In his works, E.Toffler critically assesses the future civilization and the search for the contours of the "new civilization", in particular noting that industrial civilization "does not go that way" because it led to a conflict between the natural and social, cultural forces of human existence, between the forms of industrial society and postindustrial. The analysis of the future society $E$. Toffler carried out on the basis of "information reductionism", the transition from industrialism to a new post-industrial stage should be realized with the domination of information technologies on the basis of a computer revolution. It will be accompanied by an updating of the mode of production, way of life and culture, and these updates will solve complex issues of computerization [8, p.150-158].

In the culture of informationdigital society, the problem of overcoming standards is becoming increasingly important, since it is a question of stimulating people's intellectual creative activity, and developing intercultural contacts and dialogue forms of sociality. D.Bell, who did not use the concept of "digital society", nevertheless stood at its origins, since he named its main determining factors: 1) not capital, but theoretical knowledge becomes the organizing principle of this type of society; 2) the social system is a nerve node in society; 3 ) The cybernetic revolution determines the technological criteria for the production of goods and services [9, P.48-60].

It is not by chance that D. Bell formulated specific dimensions and components of this type of society, based on the realization of the main factor of the country's intellectual potential:

1) employment: the transition from the production of goods to the production of services;

2) in the field of management: the leading role of professional specialists and technicians, managers;

3) the axial principle: the decisive role of knowledge as a source of innovation and policy definition in society;

Conceptualization of information-digital management in the conditions of technological revolution 4.0 
4) future orientation - control over technology and technological assessment of activities;

5) the decision-making process the creation of a new "intellectual technology" associated with electronic digital technologies.

It should be noted that the functioning of these components changes the ratio of the economy and the social sphere, subordinating the economy to the social sphere. The leading force of social policy determines the decisive role of the social structure of meritocracy (D. Bell), the technostructure (J. Gelbrait), that organize all types of activities and management of the society. At the helm of power - "the power of the best" - a hierarchy of scientists, managers, engineers, civil servants, due to talent, knowledge, qualifications [10].

In his "Third Wave", Toffler outlined the stages of the development of human civilization - the transition from industrial to post-industrial one, then to informational and digital one, through which humanity passes in its development:

1) pre-industrial - agricultural civilization (1650-1750), which is based on a simple division of labor, the caste structure of society, the authoritarian power of a decentralized economy.

2) industrial (1750 1950); industrialism has destroyed agricultural civilization, replacing the way of life of millions of people; the market developed; this civilization gave man a lot of material benefits, but a high price was paid for it separation from production, dictate of massization, loss of individualization, separation of the producer from the consumer; Toffler negatively assesses industrial civilization and sees a way out in its fundamental conversions, transformations, and modernization.

3) postindustrial (1950-1990) computer information, which is characterized by:

a) information (flexible) technologies that lead to the qualitative transformation of the infrastructure of society and the way people live;

b) a de-massified society in which classes lose their meaning and various transitional forms are created; transnational institutions that solve global issues - a backtrack from national-state closeness to common markets with the free movement of goods, people, ideas, finances, cultures[11].

4) digital civilization - from 19902000 and up to our days

Toffler outlined the development of the next stage of development, which includes innovations of the radical planetary transformation of society:

a) stimulation of the introduction of microprocessors and the emergence of new types of production activities (robotics, computerization);

b) birth of new forms of organization of human relations, which correspond to the specified technology (nanotechnology, biotechnology, convergent technologies, which are called high or breakthrough);

c) transformation of the way of life in the direction of assessing the quality of life. 
4) All this together led to the birth of a digital civilization, which represents a new transformation of the social world (1980 to the present time), which can be called ecorational, based on which information and computer systems revolutionize technological processes (microelectronics, bio and light technologies, robotics, nanotechnologies), which open the way to a green industry, diversificational, decentralized, resource-saving production [12].

At the same time, McLuhan also believed that the electronic revolution would radically change life on the planet. At the initial stage, electronic technologies (space communications, portable video recording) performed the role of social therapy. They created a new type of social communication [13].

At higher stages of its development, the electronic revolution led to fundamental social changes, which are characterized by three major innovations: 1) satellite communications; 2) the creation of fiber optic cable networks, digital electronic devices; 3) the use of microprocessors integrated circuits for the rapid application of information transfer, which gives everyone access to the database anywhere in the world. Similar intellectual and technological systems led to a fundamentally new stage of civilization and culture and the emergence of global hyperintelligence (data and knowledge industry) [14].

Computerization, followed by digitalization, created the technological basis for informatization of society, in which informatics and computers together with the second literacy contributed to the enhancement of human intellectual and creative abilities, and in general, the intellectual capital of the society. Informational technologization and digitalization of social life contributed to the formation of a new concept of digitalization of society, in which information and its digitalization represents power. Information and digitalization have replaced the social revolution [15].

We do not fight with machines, we turn into a part of "technological singularity". Scientists believe that over time people will create more intelligence and history will reach a kind of singularity, that is, unprecedented intellectual development, that is, the connection of space and time and the world can go beyond of our understanding [16, p.256-263].

\section{Conclusions and practical recommendations.}

The concept of information-digital management should be introduced in all areas of development of society, including higher education, which requires the formation of an intellectual creative personality, as a subject of information and innovative society of digital civilization. Digital civilization will contribute to further digitalization of society, its implementation in all spheres of human life, as there will be a total digitization of everything that can be imagined in this area: innovation, artificial intelligence, computer welfare, the development of various

Conceptualization of information-digital management in the conditions of technological revolution 4.0 
convergent

(breakthrough)

technologies. There will be a reduction in workplaces, as computers will enter into every organization and life, and there will be a "human battle with machines". Computerization will totally affect our life, economy, politics, social, cultural and other spheres of development. Therefore, it is necessary to form successful innovative strategies and make every effort for the further development of digital society, which is based on the development of intellectual human capital. According to the latest data, there are already more than 2 billion smartphones in the world and we cannot imagine our life without them. The current generation will work hand in hand with robots, will not be surprised by the results of big data analysis using artificial intelligence and will find the answer to the question - artificial intelligence is good or evil for humanity. Digital generation or generation $\mathrm{Z}$ - this generation, born after 1995 and never knowing the time without the Internet, they are accompanied by these devices from childhood, they cannot be surprised by cryptocurrency or new technologies like blockchain, they will become global citizens rather than hired employees. The future development of society is digital development, which requires the formation of a digital consciousness, digital culture, digital worldview. The digital identity will become the object and subject of the digital society.

\section{REFERENCES}

1. Voronkova, V. H. (2017). The formation of the smart community as a factor of sustainable development and its influence on the formation of a new educational paradigm. Gìleâ,117 (2), 189-193.

2. Voronkova, V. H. (2015). The civil society as a paradigm, concept and social construct fhilosophical discourseю. Philosophy and cosmology. Kyiv: ISPC, 15, 198-215.

3. Brignollsson, E. and Makafi, E. (2016). Second era of machines: work, progress and prosperity in times of extraordinary technologies. Kyiv: FUND, 236.

4. James, P. Womack, D. and Jones, T. and Rus, D. (2017). The machine that changed the world." History of line production - dark weapons "Toyota" in automotive wars. Library Lin Institute. Kyiv: Pavlum, Lean Snicit Ukraine, 388.

5. Rogers, E. M. (2009). Diffusion of innovations. Kyiv: Publishing House: KyivMohylian Academy, 591.

6. Donell, M. and Meadows, D., Randers, J. (2018). Borders of growth. 30 years later. Kyiv: Pavlum, 454.

7. Melnyk, V. V. (2018). Information management as a factor of innovative society development. Humanities Bulletin of Zaporizhzhe State Engineering Academy, 74, 39-47.

Doi: https://doi.org/10.30839/2072-7941.2018.149651

8. Nikitenko, V. O. (2018). Education as a factor of creative personality establishment and development in information society. Humanities Bulletin of Zaporizhzhe State Engineering Academy, 74, 150-158.

Doi: https://doi.org/10.30839/2072-7941.2018.149674

9. Punchenko, O. P. and Voronkova, V. H. and Andriukaitiene, R. (2018). Sociodynamics of the globalizing world in its civilization dimension. Humanities Bulletin of Zaporizhzhe State Engineering Academy, 74, 48-60.

Doi: https://doi.org/10.30839/2072-7941.2018.149652 
10. Rose, D. (2014). Objects: Design Human Desire and the Internet of Things New York: Scribner, 320.

11. Christopher, S. (2018). Total automation. How computer algorithms change life. Kyiv: Our format, 280.

12. Starzhinsky, V. P. (2016). Towards an Innovation Society. Minsk: RIVSh, 446.

13. Florida, R. (2018). Homo creative. How does the new class conquer the world. Kyiv: Our format, 432.

14. Ford, M. (2016). Engineering and the threat of the future. Kyiv: Our format, 400.

15. Shevchenko, A. (2018). Digital era. Just about digital technology. Kyiv: Summit Book, 457.

16. Cherep, A.V., Cherep, O.H., Krylov, D.V. and Voronkova, V. H.. (2019). .Methodological approach to the redistribution of investment projects within a company According to formal criteria // Financial and credit activity-problems of theory and practice. Volume 28, Issue 1. 256-263

DOI: https://doi.org/10.18371/fcaptp.v1i28.163991

17.Žukauskas, P., Vveinhardt, J. and Andriukaitienė R. (2018) Management Culture and Corporate Social Responsibility, London: IntechOpen, 433.

МЕЛЬНИК, В. В. - кандидат філософських наук, доцент кафедри управління, інформаційно-аналітичної діяльності та євроінтеграції,

Національний педагогічний університет імені М. П. Драгоманова (Київ, Україна)

E-mail: doc.v.melnik@mail.ru, ORCID: 0000-0001-5976-5823

\section{КОНЦЕПТУАЛИЗАЦІ ІНФОРМАЦІЙНО-ЦИФРОВОГО МЕНЕДЖМЕНТУ В УМОВАХ ТЕХНОЛОГІЧОЇ РЕВОЛЮЦЇ̈ 4.0}

\section{Анотація.}

Актуальність дослідження даної проблеми у тому, що концепція інформаційноцифрового менеджменту сприяє розвитку цифрового суспільства, в основі якого нова хвиля технологічного прогресу. Мета дослідження - показати, як інформаційна революція XXI століття сприяє покращенню робочої сили у результаті прогресуючої роботизації. Технології, які використовуються сьогодні, щоб заміти людей, $\epsilon$ розумними, потреба у людських ресурсах зменшується завдяки роботам, комп'ютерам та іншим високотехнологічним гаджетам. Методи теоретичного аналізу - дедукції та індукції, історичного і логічного, порівняльного і структурно-генетичного аналізу, інформаціологічного методу, які сприяють проникненню у сутність досліджуваного феномена як складного явища i динамічного процесу. Результати дослідження: доведено, що завдяки різноманітним відомим розробкам з інформаційно-комп'ютерних технологій та робототехніки, багато експертів вважають, що суспільство перебуває на ранньому етапі нової індустріальної (постіндустріальної) революції, яка в майбутньому може змінити спосіб життя і діяльності людей точно так, як це 200 років назад зробила парова машина. Технологічне безробіття $є$ однією 3 основних причин підвищення загального рівня безробіття у країнах Заходу за останні 30 років. Хоча це деякою мірою пов'язане 3 демографічною революцією і зміною структури економіки у багатьох країнах, розвиток інформаційно-комп'ютерних технологій, а також інших видів автоматизації та Інтернету відіграли значну роль, починаючи з 2000 року.

Висновки. Ми показали, що багато робочих місць 3 дешевою робочою силою може зникнути, тому що цифрове суспільство робить акцент на розвиток людських інтелектуальних ресурсів. Світ перетворюється на цифрове суспільство і світом управляє цифра, в основі якої управляють інтелект, розум, алгоритми, цифровізація.

Conceptualization of information-digital management in the conditions of technological revolution 4.0 
Цифрове суспільство складається 3 великої кількості алгоритмів, які управляються інформаційно-комп'ютерними технологіями, які проникають у цифровий менеджмент, який базується на інтелектуально-розумній силі, представленою людськими ресурсами. Саме людські ресурси розвивають робототехніку, штучний інтелект, комп'ютеризацію, механізацію, роботизацію, в основі яких роботехніка, штучний інтелект. Ці різновиди цифрового суспільства прискорюють потенціал довгострокового збільшення продуктивності праці за рахунок інтелектуалізації. Практичні рекомендації - розвивати малий бізнес, який тримається на мережевих інтелектуальних платформах, у зв'язку 3 чим створювати робочі місця в Інтернеті і формувати нові види зайнятості.

Ключові слова: цифрове суспільство, ідеологія інформаційно-комп'ютерних технологій, людські ресурси, цифровий менеджмент.

МЕЛЬНИК В. В. - кандидат философских наук, доцент кафедры управления, информационно-аналитической деятельности и евроинтеграции, Национальный педагогический университет имени М. П. Драгоманова (Киев,Украина)

E-mail: doc.v.melnik@mail.ru, ORCID: 0000-0001-5976-5823

\section{КОНЦЕПТУАЛИЗАЦИЯ \\ ИНФОРМАЦИОННО-ЦИФРОВОГО МЕНЕДЖМЕНТА В УСЛОВИЯХ ТЕХНОЛОГИЧЕСКОЙ РЕВОЛЮЦИИ 4.0 \\ Аннотация.}

Актуальность иследования данной проблемы в том, что концепция информационно-цифрового менеджмета способствует развитию цифрового общества, в основе которого новая волна технологического прогресса. Цель исследования показать, как информационная революция XX1 века способствует сокращению рабочей силы в результате прогрессирующей роботизации. Технологии, которые используются сегодня, чтобы заменить людей, есть разными, потребность в человеческих ресурсах уменьшается благодаря роботам, компьютерам и другим высокотехнологическим гаджетам. Методы теоретического анализа - дедукции и индукции, исторического и логического, сравнительного и структурно-генетического анализа, информациологического метода, которые способствуют проникновению в сущность исследуемого феномена как сложного явления и динамического процесса.

Результаты исследования: доказано, что благодаря разнообразным известным разработкам в информационно-компьютерным технологиям и робототехнике, много экспертов считают, что общество пребывает на раннем этапе новой индустриальной (постиндустриальной) революции, которая в будущем может изменить способ жизни и деятельности людей точно также, как как 200 лет назад сделала паровая машина. Технологическая безработица есть одной из основных причин повышения общего уровня безработицы в странах Запада за последние 30 лет. Хотя в некоторой мере это связано с демографической революцией и сменой структуры экономики во многих странах, развитие информационно-компьютерных технологий, а также других видов автоматизации и Интернета сыграли значительную роль, особенно, начиная с 2000 года.

Выводы. Мы показали, что много рабочих мест с дешевой рабочей силой может исчезнуть, потому что цифровое общество делает акцент на развитие человеческих (интеллектуальных) ресурсов. Мир превращается в цифровое общество и миром правит цифра, в основе которого управляют интеллект, разум, алгоритмы, цифровизация. Цифровое общество состоит из множества алгоритмов, которые управляются информационно-компьютерными технологиями, которые проникают в цифровой менеджмент, который базируется на интеллектуально-разумной силе, представленной человеческими ресурсами. Именно человеческие ресурсы развивают робототехнику, искусственный интеллект, компьютеризацию, механизацию, роботизацию, в основе которых робототехника, искусственный интеллект. Эти разновидности цифрового 
общества ускорят потенциал долгосрочного увеличения производительности труда за счет интеллектуализации. Практические рекомендации - развивать малый бизнес, который держится на сетевых интеллектуальных платформах, в связи с чем создавать рабочие места в Интернете и формировать новые виды занятости.

Ключевые слова: цифровое общество, идеология информационно-компьютерных технологий, человеческие ресурсы, цифровой менеджмент

Стаття рекомендована до публікаиії д.філос.н., проф. І.С.Рижовою (Запоріжжя, Україна) Надійшла до редколегії: 08.07.2019 p. Прийнята до друку: 18.07.2019 р.

Conceptualization of information-digital management in the conditions of technological revolution 4.0 